\title{
INVESTIGATING NATURAL TREATMENT FACTORS AND INEQUALITIES OF MEDICINAL WATER INSTITUTIONS IN THE ASPECT OF TOURISM IN HUNGARY
}

\author{
Ágnes Erzsébet HOJCSKA* \\ Békés County Central Hospital, 1. Semmelweis street, 5700 Gyula, Hungary, e-mail: h.agnes.erzsebet@gmail.com
}

\section{Zoltán SZABÓ}

Hungarian University of Agriculture and Life Sciences, Georgikon Campus, Institute of Sustainable Development and Farming, Department of Sustainable Tourism, 16. Deák Ferenc street, 8360 Keszthely, Hungary, e-mail: Szabo.Zoltan.dr@uni-mate.hu

Citation: Hojcska, A.E., \& Szabó, Z. (2021). INVESTIGATING NATURAL TREATMENT FACTORS AND INEQUALITIES OF MEDICINAL WATER INSTITUTIONS IN THE ASPECT OF TOURISM IN HUNGARY. GeoJournal of Tourism and Geosites, 36(2spl), 555-562. https://doi.org/10.30892/gtg.362spl01-683

\begin{abstract}
The aim of the research is to reveal the spatial inequalities of the natural treatment factors in Hungary and the medicinal water institutions built on them, with the help of spatial research methods on the basis of secondary data. Due to the favorable geographical conditions of Central Europe, the Carpathian Basin has a considerable amount of natural resources. With the appreciation of health, in our days they represent significant value because they are becoming increasingly important in tourist services aimed at maintaining and restoring health. In Hungary, there are outstanding opportunities for this in health tourism, which provides a wide range of medical services, including medical tourism based on natural treatment factors. In order to achieve the set research goal, we used the range of the data set (range-ratio), the dispersion range (range), the relative range (relative range) and the dual measure (Éltetö-Frigyes-index) as spatial inequality test methods for the geographically based examination of Hungary's natural treatment factors and the system of medicinal water institutions. The research results show that the spatial polarisation of natural treatment factors and the medicinal water institutions based on them show significant inequalities in Hungary. It has been proved that the development of the counties is outstanding in terms of medicinal waters and medicinal bath, and the spatial difference is also the lowest in the case of these treatment factors.
\end{abstract}

Key words: medicinal water institutions, medicinal water, medicinal bath, natural treatment factors, spatial polarisation

$* * * * * *$

\section{INTRODUCTION}

In the Carpathian Basin, Hungary has an outstanding geographical and hydrogeological conditions, which appear primarily through the empirical and evidence-based use of natural treatment factors, providing an opportunity for the geographically based development of tourism. As health is becoming more and more valuable in today's fast-paced world, its role in tourism is becoming more and more apparent (Bauer, 2008). Health tourism trips, including those based on natural treatment factors, play a prominent role in the preservation of health abroad and in Hungary (Szabó, 2017). There are a significant number of natural treatment factors and the medical services based on them in the world and in Hungary as well, but the research focus primarily on the formation (Bookman, 2007), conceptual system (Carrera and Bridges, 2006) and development (Cook, 2008) of medical tourism, or examines the medical and health tourism aspects and products of a smaller spatial unit (Dávid et al., 2013).

In Hungary, health tourism is based on special medicinal water treatments and the institutional system providing them, which are mainly financed by the National Health Insurance Fund of Hungary. The study of spatial differences in this specific system has not yet been the subject of scientific research. Therefore, the authors of the present study make an attempt to comprehensively investigate the natural treatment factors and meicinal water institutions in Hungary. Among natural resources, Hungary is internationally recognized (Szabó, 2012) thanks to its natural treatment factors (Hojcska and Szabó, 2016). In Hungary, five types of natural treatment factors can be used in medicinal water treatments as a health tourism product (Bujdosó, 2011), which are available in many places in the country. These treatments provide a conservative treatment option for patients, especially in cases of musculoskeletal disorders in medicinal water institutions. The aim of our research is to promote the geographically based development of tourism by exploring the resources of Hungarian medical tourism. In order to achieve our research goal, the natural treatment factors and the system of medicinal water institutions of Hungary will be explored on a geographical basis, using modern inequality studies. Our research is relevant, because the efficient development of the resources of Hungarian medical tourism is a precondition in order to be internationally acknowledged. The aim of the research is to reveal the spatial inequalities of the natural treatment factors in Hungary and the medicinal water institutions built on them, with the help of spatial research methods on the basis of secondary data.

\section{LITERATURE REWIEV}

Due to its geographical position, Hungary has an outstanding quantity and quality of natural treatment factors in the world, primarily medicinal waters (Bender et al., 2013). As a result, natural treatment factors appear as health care products in the health care industry, and their spatial differences are also important from a tourism point of view (Bujdosó, 2018). Within 
tourism, medical tourism plays a key role with the increasing emphasis on health among the population. As health is becoming more and more appreciated, there is an increasing emphasis on preserving it. The pursuit of a healthier lifestyle provides a significant motivation for a new health-oriented lifestyle, which includes turning to nature and increasing the use of natural therapies (Botterill et al., 2013). The use of natural values and natural areas within and outside the country (Ilieș et al., 2010) for health-preserving sports and tourism activities (Ilies et al., 2018) can contribute to maintaining health. Medical tourism based on medical services also plays an increasing role (Géher et al., 2016; Csapó and Marton, 2017) besides the importance of preventive and recreational travel and services (Fritz, 2019). This is based on the natural treatment factors of natural resources, which include healing climates, medicinal caves, medicinal gases, medicinal mud, medicinal soils, and thermal waters (Dávid et al., 2007), as well as medicinal thermal waters certified by special procedures in Hungary (Csermely, 2009).

Hot water has been used for thousands of years by different peoples to bath, refresh and relieve musculoskeletal problems. There were already public baths in ancient Greece and Rome, then they were used for healing and recreational care by wounded soldiers, and later the use of thermal waters as a bath and drinking cure appeared as a treatment (Van Tubergen and Van der Linden, 2002; Ákoshegyi and Németh, 2006). After the Roman and Greek bathing cultures, there was a decline in bathing life in the Middle Ages, followed by slow development again. Then, physiotherapy procedures, medicinal water treatment and balneo therapy developed more vigorously with the European (France, Germany) recovery in the 18th and 19th century (Kovács, 2017). In balneotherapy, medicinal waters are used in curative procedures, but it is associated with the use of medicinal muds and natural medicinal gases in medical treatment, which can be part of prevention, curation and rehabilitation for many diseases. Nevertheless, there are significant differences between countries in the practical application, reimbursement, education, and research of balneotherapy (Cantista, 2012). In Europe, Hungary has played a prominent role in balneotherapy and spa tourism using natural treatment factors since the 19th century. In Hungary, an internationally outstanding number of natural treatment factors are under legal protection. The medicinal water institutions (medicinal baths, medicinal hotels, health resorts) built on these treatment factors provide the spa treatment services that form the basis of spa tourism (Hojcska and Kurth, 2016) in almost all areas of the country, under strict regulation. Nowadays, natural treatment factors are mainly used in health tourism (Molnár and Dávid, 2010), within which these factors are used in the sector of medical tourism. In this sector, there are significant differences in terminology, service supply and finance in different parts of the world (Hall, 2013). Zsarnóczky dealt with the systematization and summary of these (Zsarnóczky, 2019). His results suggest that while in Asian countries (India, Singapore, Taiwan, and Thailand) high-quality medical services fall into this category, in Brazil, Turkey, and Russia, in addition to medical services, traditional procedures are in the focus of medical tourism. Furthermore, in these countries, medical tourism destinations are represented by private institutions that provide services based on market demand, without the involvement of insurers.

The medical tourism system of the countries of North America is operated by service providers with a similar structure to Asia and providing the most complex wellness tourism packages with the assistance of private insurers. However, the system of health tourism in Europe, and its medical tourism, is completely different from the previous ones, especially with regard to the Carpathian Basin (Szabó, 2011). The reason is that there are a significant number of natural treatment factors here, the application of which in medicine is mostly based on the system of national health insurers (Zsarnóczky, 2017). Among the natural treatment factors, medicinal mud (Babov et al., 2020), medicinal caves (Lăzărescu, 2014; Nagy et al., 2008), medicinal gases (Modelska et al., 2015; Incze, 2016) and medicinal waters are the most commonly used in medical tourism (Gutenbrunner, 2010; TeoibasSerban, 2020). Overall, it can be concluded from the research of Munteanu and his coauthors (2020) that among the natural treatment factors, the health use of thermal waters is found and widespread on almost every continent; in the Middle East and Southeast Europe, Asia, South America and North Africa, but Central Europe has the most significant and highest temperature thermal water reserves on which many baths have been built (Bachvarov and Liszewski, 2004; Jordan, 1999).

\section{MATERIALS AND METHODS}

In order to achieve the set research goal, we carried out secondary research, during which we used and analyzed the data of the natural treatment factors and medicinal water institutions in Hungary included in the register of the National Public Health and Medical Officer Service (NPHMOS). The analyses were performed according to the NUTS3 (nomenclature des unités spatiales statistiques = Nomenclature of Spatial Units for Statistics) unified spatial division system, which includes 19 counties of Hungary and Budapest, forming a total of 20 survey spatial units (Goll, 2010). In accordance with the research goal, we use spatial inequality test methods for the geographically based examination of Hungary's natural treatment factors and the system of medicinal water institutions in order to achieve complex test results. Four of these methods are used to study spatial polarisation.

The indicators measuring spatial polarisation are to compare the most developed and underdeveloped areas of the studied territorial units. Our first measure used to measure spatial polarisation is the range of the data set (range-ratio), which is the quotient of the maximum and minimum values occurring in the examined data set. The minimum value of the results is 1 , there is no upper limit. Its advantage is that it is easy to calculate, but its disadvantage is that only the two extreme values are taken into account, but the distribution is not. Its symbol is „K”, its formula is (Noether, 1955): $\mathrm{K}=\mathrm{X}_{\max } / \mathrm{X}_{\min }$ where $\mathrm{X}_{\max }=$ the maximum value of the data set, $x_{\min }=$ the minimum value of the data set (Molnár, 2015). In this research, this means how many times difference is there between the two extreme values of the data set containing the natural treatment factor and the medicinal water institution which were examined by county. The second polarity measure used is the dispersion range measure (range). It is easy to calculate, easy to interpret, but its disadvantage is that only the maximum and minimum value data are taken into account by this measure.

Its symbol is " $R$ ", its formula is (Tippett, 1925): $R=x_{\max }-x_{\min }$ where $x_{\max }=$ the maximum value of the data set, $x_{\min }=$ the minimum value of the data set (Németh, 2005). This polarisation measure shows the largest difference in the number of natural treatment factors and medicinal water institutions in the counties in our investigation. The third measure of spatial polarisation we 
use is relative range (relative range). This measure is also suitable for comparing data series with different averages, as well as for comparing data series with different units and magnitudes. Its symbol is „Q", its formula is: $Q=\left(x_{\max }-x_{\min }\right) / \bar{X}$ where $x_{\max }=$ the maximum value of the data set, $x_{\min }=$ the minimum value of the data set, $\bar{x}=$ the average of the data set examined (Molnár, 2015). In our research, we use this measure to determine how the average number of natural treatment factors and medicinal water institutions in the examined county relates to the difference between the maximum and minimum values of the same factors.

The fourth measure examining spatial polarisation is the dual measure (Éltetö-Frigyes-index), published in 1968 by Hungarian statisticians Ödön Éltető and Ervin Frigyes. Its symbol is „D”, its formula is: $\mathrm{D}=\overline{\mathrm{X}}_{\mathrm{m}} / \overline{\mathrm{X}}_{\mathrm{a}}$ where $\mathrm{x}_{\max }=$ the maximum value of the data set, $x_{\min }=$ the minimum value of the data set, $\bar{x}=$ the average of the data set examined, $\bar{x}_{m}=$ the average of the values above the average, $\bar{x}_{a}=$ the average of the values not exceeding the the average (Nemes Nagy, 2006; Major and Nemes Nagy, 1999). This measure gives the quotient of the average of the values above the average of the total distribution and the average of the values below the average of the total distribution in the counties on which our study is based in relation to the natural treatment factors and medicinal water institutions. With these four measures we can safely determine the spatial differences of natural treatment factors and medicinal water institutions, as well as the development of Hungarian counties in terms of natural treatment factors and the system of medicinal water institutions (Cowell, 1977; Williamson, 1965). Thus, our research goal can be achieved.

\section{LIMITATION OF THE STUDY}

To evaluate the results, it is important to identify the limitations of the present research, which, like most studies, have limited the design and conduct of the current study. The limitation of the research is the limited literature relevant to the topic. In Hungary, the use of the large numbers of natural treatment factors in medical tourism partly differs from the international one, and this gives the literature limitation of the research. Therefore, there are only a few possibilities to compare the different literatures in the topic (Price and Muran, 2004).

\section{RESULTS AND DISCUSSION}

In our research, we endeavoured to make the results of our planned study suitable for the development of geography-based tourism, which is a precondition for Hungarian medical tourism to be internationally acknowledged. In order to achieve this, natural treatment factors in Hungary and the spatial polarisation of the medicinal water institutions based on them by counties are explored.

\section{Geographical division of Hungary's natural treatment factors and medicinal water institutions}

The data suggest that five types of Hungary's natural treatment factors (medicinal water, medicinal mud, medicinal cave, medicinal gas) are used as natural resources in medical tourism, primarily in medicinal water institutions. These natural treatment factors and medicinal water institutions based on them can be found in different numbers in the counties of Hungary which are illustrated in Table 1. Overall, the natural treatment factors in Hungary include 270 medicinal waters, five medicinal mud, five medicinal caves, two medicinal gases, and the medicinal water institutions built on them include 98 medicinal baths, 40 medicinal hotels and 32 health resorts.

Table 1. Hungary's natural treatment factors and medicinal water institutions (NUTS3) (Source: Based on ÁNTSZ 2019, own editing)

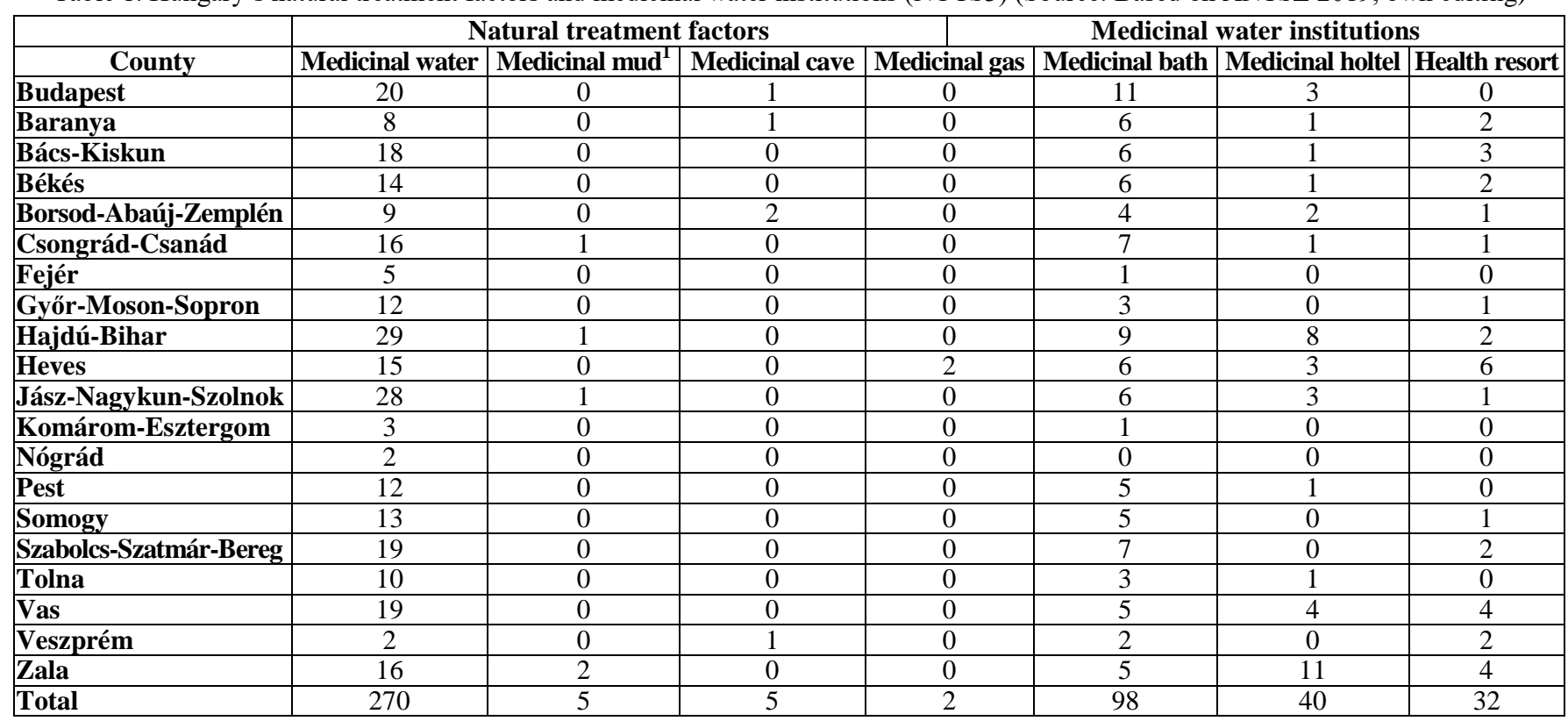

\section{Geographical inequalities of natural treatment factors}

In the first part of our research, the geographical inequalities of Hungarian medicinal waters, medicinal mud, medicinal caves and medicinal gases as natural treatment factors are explored using four methods suitable for the examination of spatial polarisation.

\footnotetext{
${ }^{1}$ The medicinal mud of Neydharting in Austria is also on the register of National Public Health and Medical Officer Service, which is not part of our calculations, as it is not located in Hungary
} 


\subsection{Spatial polarisation of medicinal waters}

Mineral water can be declared medicinal water when undergoing a special procedure, and when its medical effect has been proven by medical examinations. Hungary has the highest number of certified medicinal waters in Hajdú-Bihar County (11\%) and the smallest number $(0.7 \%)$ in Nógrád County compared to the total number of medicinal waters (Table 2).

Table 2. Spatial polarisation of medicinal waters by counties (NUTS3) (Source: Own editing and calculation)

\begin{tabular}{|c|c|c|c|c|c|c|c|c|c|c|c|c|c|c|c|c|c|c|c|c|c|c|}
\hline & \multicolumn{10}{|c|}{ Undeveloped counties } & \multicolumn{12}{|c|}{ Developed counties } \\
\hline $\begin{array}{l}\stackrel{\Xi}{\Xi} \\
\text { 己े }\end{array}$ & 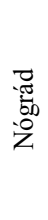 & 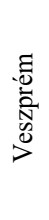 & 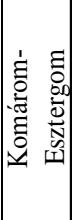 & $\frac{\vec{d}}{\frac{\vec{d}}{\Phi}}$ & 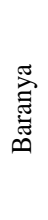 & 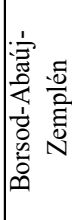 & $\frac{\mathfrak{\Xi}}{0}$ & 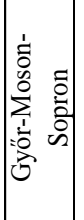 & 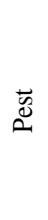 & 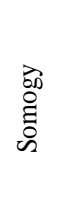 & 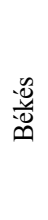 & 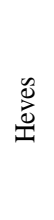 & 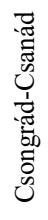 & $\frac{\pi}{\text { N }}$ & 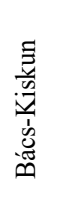 & 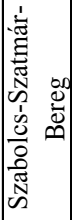 & $\stackrel{\tilde{z}}{>}$ & 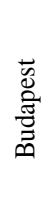 & 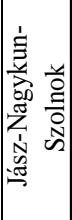 & 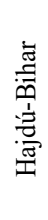 & 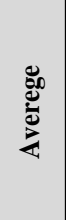 & हूँ \\
\hline Piece & 2 & 2 & 3 & 5 & 8 & 9 & 10 & 12 & 12 & 13 & 14 & 15 & 16 & 16 & 18 & 19 & 19 & 20 & 28 & 29 & 13.5 & 270 \\
\hline
\end{tabular}

Table 3. Spatial polarisation of other natural treatment factors by counties (NUTS3) (Source: Own editing and calculation)

\begin{tabular}{|c|c|c|c|c|c|c|c|c|c|c|c|c|c|c|c|c|c|c|c|c|c|c|}
\hline & \multicolumn{11}{|c|}{ Undeveloped counties } & \multicolumn{9}{|c|}{ Developed counties } & \multirow[b]{2}{*}{ 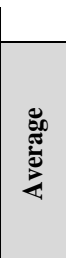 } & \multirow[b]{2}{*}{ है } \\
\hline 音 & 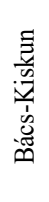 & $\begin{array}{l}\text { 岕 } \\
\text { 岕 }\end{array}$ & 漓 & 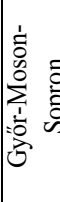 & 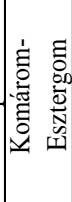 & 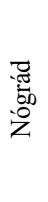 & $\begin{array}{c}\vec{v} \\
\text { s. }\end{array}$ & 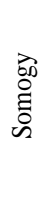 & 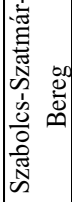 & $\stackrel{\frac{\pi}{0}}{\stackrel{\Xi}{0}}$ & $>_{7}^{\frac{\pi}{2}}$ & 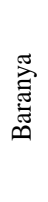 & 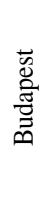 & 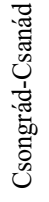 & 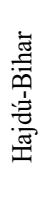 & 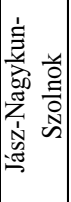 & 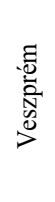 & 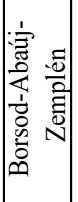 & 岂 & $\frac{\pi}{\mathbb{N}}$ & & \\
\hline Piece & 0 & 0 & 0 & 0 & 0 & 0 & 0 & 0 & 0 & 0 & 0 & 1 & 1 & 1 & 1 & 1 & 1 & 2 & 2 & 2 & 0.6 & 12 \\
\hline
\end{tabular}

When examining the spatial polarisation of the medicinal waters, we were also the first to determine the range ratio, the result of which has been $K=29 / 2=14.5$. Based on this result, we found that in the case of Hungarian medicinal waters, there is a 14.5-fold difference between the counties with the least medicinal water and the counties with the most medicinal water. Second, we calculated the dispersion range measure of medicinal waters, the result of which has been $\mathrm{R}=29-2=$ 27. This result shows the difference between the number of medicinal water elements in the county with the most and the least medicinal water, which is 27 . Third, we calculated the relative range the result of which has been $Q=(29-2) / 13.5=2$. This result shows that the difference between the counties with the most and the least number of medicinal water elements related to the average is two. The fourth measure, the dual index shows the relation between the averages of the number of medicinal waters above the average distribution of the total number of medicinal waters and the average of the number of elements that had fallen below the average distribution of medicinal waters in the counties.

The result of this quotient is $\mathrm{D}=19.4 / 7.9=2.5$. Therefore, we concluded that there is a 2.6-fold difference between the most developed and the least developed counties in terms of medicinal waters. Ten counties in Hungary have a better-thanaverage supply of medicinal water, most of which are located in Hajdú-Bihar (29) and Jász-Nagykun-Szolnok (28) counties. Nine counties have below-average supply of medicinal water, the least of which can be found in Nógrád and Veszprém counties (two each) and Komárom-Esztergom County (three). These differences in the quantity of medicinal water are mainly explained by the differences in natural geographical conditions and the difference in the distribution of evidence based medicine (EBM) research required for declaration as medicinal water (Bender et al., 2014).

\subsection{Spatial polarisation of other natural treatment factors}

As the natural treatment factors such as medicinal mud, medicinal cave and medicinal gas can be found in small quantities in the counties of Hungary compared to the quantity of medicinal waters, the spatial polarisation can only be partially investigated in their case. In the case of medicinal mud, we found that Zala County (40\%) has the most medicinal mud in Hungary and Csongrád-Csanád, Hajdú-Bihar and Jász-Nagykun-Szolnok Counties (20\%-20\%-20\%) have the least, in addition to the fact that no medicinal mud is found in any other county of the country. Examining the caves, we determined that most of the caves are located in Borsod-Abaúj-Zemplén County (40\%), the least in Budapest, Baranya and Veszprém Counties (20\%-20\%-20\%), there are no other medicinal caves in the country. Regarding medicinal gases, we found that the most (two) and the only natural medicinal gas is in Heves County. In order to analyze the s patial polarisation more accurately, we summarized the number of these natural treatment factors by counties and analyzed them together (Table 3). When examining the spatial polarisation of other natural treatment factors, we first determined the range ratio, the result of which has been $\mathrm{K}=2 / 1=2$. On the the basis of this result it can be stated that in the case of Hungary, there is a twofold difference between the counties with the fewest and most medicinal mud, medicinal caves and medicinal gas. Second, we determined the dispersion range measure, the result of which has been $\mathrm{R}=2-1=1$.

This result shows the difference between the number of elements in the county with the most and the fewest other natural treatment factors, which is one other natural treatment factor. Third, we calculated relative range, the result of which has been $\mathrm{Q}=(2-1) / 0.6=1 / 0.6=1.7$. This result shows that the difference between the counties with the most and the least number of other natural treatment factor elements related to the average is 1.7. The fourth measure, the dual index shows the relation between the averages of the number of natural treatment factos above the average distribution of the total 
number of natural treatment factors and the average of the number of elements that had fallen below the average distribution of natural treatment factors in the counties. The result of this quotient is $\mathrm{D}=1.3 / 0=\mathrm{N} / \mathrm{A}^{2}$.

Table 4. Spatial polarisation of medicinal baths by counties (NUTS3) (Source: Own editing and calculation)

\begin{tabular}{|c|c|c|c|c|c|c|c|c|c|c|c|c|c|c|c|c|c|c|c|c|c|c|}
\hline & \multicolumn{7}{|c|}{ Undeveloped counties } & \multicolumn{13}{|c|}{ Developed counties } & \multirow[b]{2}{*}{ 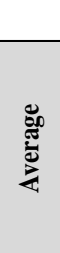 } & \multirow[b]{2}{*}{ 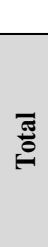 } \\
\hline 音 & 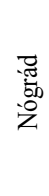 & : & 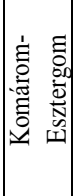 & 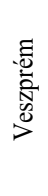 & 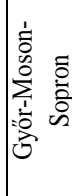 & $\stackrel{\Xi}{\circ}$ & 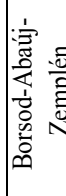 & $\begin{array}{l}\vec{w} \\
\stackrel{s}{s}\end{array}$ & 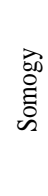 & $\stackrel{\mathscr{7}}{>}$ & 㞼 & 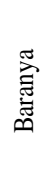 & 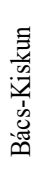 & 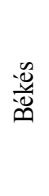 & 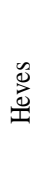 & 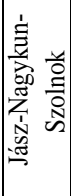 & 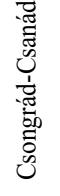 & 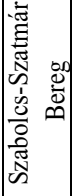 & 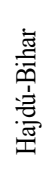 & 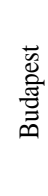 & & \\
\hline Piece & 0 & 1 & 1 & 2 & 3 & 3 & 4 & 5 & 5 & 5 & 5 & 6 & 6 & 6 & 6 & 6 & 7 & 7 & 9 & 11 & 4.9 & 98 \\
\hline
\end{tabular}

Table 5. Spatial polarisation of medicinal hotels by counties (NUTS3) (Source: Own editing and calculation)

\begin{tabular}{|c|c|c|c|c|c|c|c|c|c|c|c|c|c|c|c|c|c|c|c|c|c|c|}
\hline & \multicolumn{13}{|c|}{ Undeveloped counties } & \multicolumn{7}{|c|}{ Developed counties } & \multirow[b]{2}{*}{ 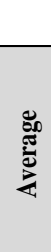 } & \multirow[b]{2}{*}{ हूँ } \\
\hline 总 & : & 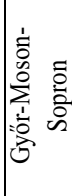 & 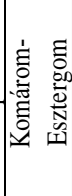 & 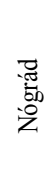 & 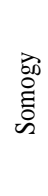 & 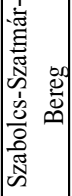 & 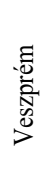 & 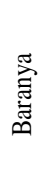 & 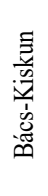 & 总 & 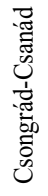 & 峞 & $\frac{\mathfrak{g}}{\stackrel{0}{\circ}}$ & 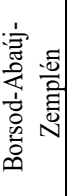 & 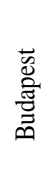 & 岂 & 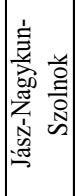 & $\stackrel{2}{\infty}$ & 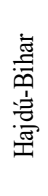 & $\frac{\pi}{\mathbb{N}}$ & & \\
\hline Piece & 0 & 0 & 0 & 0 & 0 & 0 & 0 & 1 & 1 & 1 & 1 & 1 & 1 & 2 & 3 & 3 & 3 & 4 & 8 & 11 & 2 & 40 \\
\hline
\end{tabular}

Table 6. Spatial polarisation of health resorts by counties (NUTS3) (Source: Own editing and calculation)

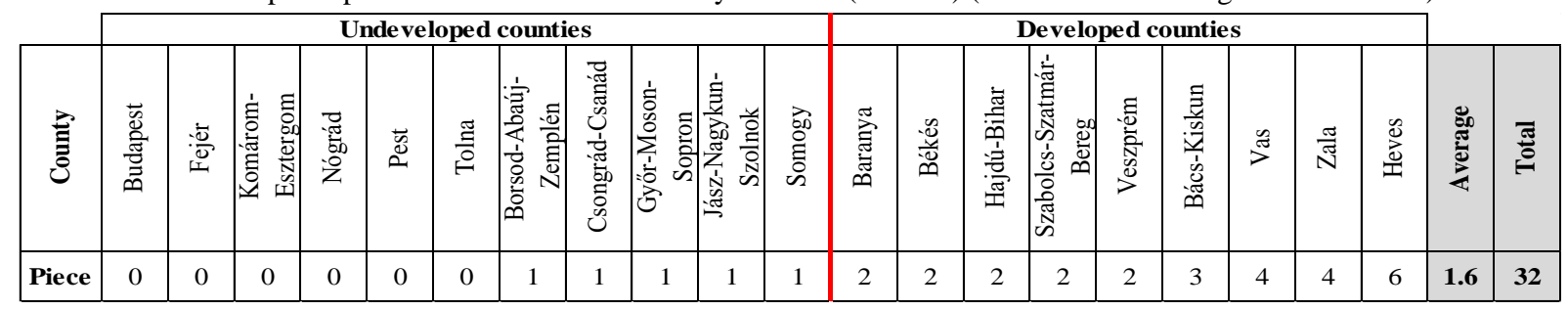

Table 7. Summary of polarisation measures $\left(\mathrm{N} / \mathrm{A}^{3}\right)$ (Source: Own editing and calculation)

\begin{tabular}{|c|c|c|c|c|c|}
\cline { 2 - 6 } \multicolumn{1}{c|}{} & \multicolumn{2}{c|}{ Natural treatment factors } & \multicolumn{2}{c|}{ Medicinal water institutions } \\
\cline { 2 - 6 } & Medicinal waters & $\begin{array}{c}\text { Other natural treatment } \\
\text { factors }\end{array}$ & Medicinal baths & Medicinal holtels & Health resorts \\
\hline Range & 14.5 & 2 & 11 & 11 & 6 \\
\hline Dispersion range & 27 & 1 & 2.04 & 10 & 5 \\
\hline Relative range & 2.2 & 1.7 & 3.3 & 9.8 & 6 \\
\hline $\begin{array}{c}\text { Dual measure } \\
\text { (Éltető - Frigyes index) }\end{array}$ & 2.5 & N/A & & 5.1 & 6 \\
\hline
\end{tabular}

\section{Geographical inequalities of medicinal water institutions}

There are a significant number of medicinal water institutions based on natural treatment factors (98 medicinal baths, 40 medicinal hotels, 32 health resorts). We also examined their spatial polarisation.

\subsection{Spatial polarisation of medicinal baths}

Compared to the total number of medicinal baths, Budapest has the highest (11\%), Fejér and Komárom-Esztergom Counties have the lowest number (1\%-1\%) of medicinal baths, not counting Nógrád County as there is no such institution there (Table 4). When examining the spatial polarisation of medicinal baths, first we determined the range ratio, the result of which has been $K=11 / 1=11$. On the basis of this result it can be stated that in the case of Hungary, there is an elevenfold difference between the counties with the fewest and most medicinal baths. Second, we determined the dispersion range measure, the result of which has been $\mathrm{R}=11-1=10$. This result shows the difference between the number of medicinal bath elements in the county with the most and the least medicinal baths, which is ten. Third, we calculated relative range, the result of which has been $\mathrm{Q}=(11-1) / 4.9=10 / 4.9=2.04$. This result shows that the difference between the counties with the most and the least number of other medicinal bath elements related to the average is 2.04 . The fourth measure, the dual index shows the relation between the averages of the number of medicinal baths above the average distribution of the total number of medicinal baths and the average of the number of elements that had fallen below the average distribution of medicinal baths in the counties. The result of this quotient is $\mathrm{D}=6.5 / 2=3.3$. From this it can be concluded that there is a 3.3-fold difference between the most developed and the least developed counties in terms of medicinal baths.

${ }^{2}$ Data is not applicable because divsion by zero is undefined in Mathematics

${ }^{3}$ Data is not applicable because divsion by zero is undefined in Mathematics 
There are 13 counties in Hungary with better-than-average medicinal bath supply, most of which are in Budapest (eleven), Hajdú-Bihar (nine) and Szabolcs-Szatmár-Bereg (seven) Counties. On the contrary, there are seven counties with below-average medicinal bath supply. The fewest medicinal baths are located in Fejér and Komárom-Esztergom Counties (one each) and in Veszprém county (two), taking into account that no medicinal baths are available in Nógrád County. These differences in the quantity of medicinal baths are mainly due to the natural geographical conditions in the counties.

\subsection{Spatial polarisation of medicinal hotels}

There are 40 medicinal hotels in Hungary. Most of them are located in Zala County (28\%). Baranya, Bács-Kiskun, Békés, Csongrád-Csanád, Pest and Tolna Counties have the least of these medicinal hotels, whereas Fejér, Győr-MosonSopron, Komárom-Esztergom, Nógrád, Somogy, Szabolcs-Szatmár-Bereg and Veszprém County have none (Table 5).

When examining the spatial polarisation of medicinal hotels, first we determined the range ratio, the result of which has been $\mathrm{K}=11 / 1=11$. On the basis of this result it can be stated that in the case of Hungary, there is a 14.5-fold difference between the counties with the fewest and most medicinal hotels. Second, we determined the dispersion range measure of medicinal hotels, the result of which has been $\mathrm{R}=11-1=10$. This result shows the difference between the number of medicinal hotel elements in the county with the most and the least medicinal hotels, which is ten. Third, we calculated relative range, the result of which has been $\mathrm{Q}=(11-1) / 2=10 / 2=5$. This result shows that the difference between the counties with the most and the least number of other medicinal hotel elements related to the average is 5 . The fourth measure, the dual index shows the relation between the averages of the number of medicinal hotels above the average distribution of the total number of medicinal hotels and the average of the number of elements that had fallen below the average distribution of medicinal hotels in the counties. The result of this quotient is $\mathrm{D}=4.9 / 0.5=9.8$.

From this it can be concluded that there is a 9.8 -fold difference between the most developed and the least developed counties in terms of medicinal hotels. There are seven counties in Hungary with better-than-average medicinal hotel supply, most of which are in Zala (eleven) and Hajdú-Bihar (eight) Counties. There are nine counties with below-average medicinal hotel supply. The fewest medicinal hotels are located in Baranya, Bács-Kiskun, Békés, Csongrád-Csanád, Pest and Tolna (one each) Counties, taking into account that no medicinal hotels are available in Fejér, Győr-Moson-Sopron, KomáromEsztergom, Nógrád, Somogy, Szabolcs-Szatmár-Bereg and Veszprém Counties. The number of qualified medicinal waters in these counties mainly cause these differences in the quantity of medicinal hotels.

\subsection{Spatial polarisation of health resorts}

The largest number of health resorts in Hungary is in Heves County (19\%), while five counties (Fejér, KomáromEsztergom, Nógrád, Pest, Tolna) and Budapest do not have such medicinal institutions at all (Table 6).

When examining the spatial polarisation of health resorts, first we determined the range ratio, the result of which has been $\mathrm{K}=6 / 1=6$. On the basis of this result it can be stated that in the case of Hungary, there is a 6 -fold difference between the counties with the fewest and most health resorts. Second, we determined the dispersion range measure of health resorts, the result of which has been $\mathrm{R}=6-1=5$. This result shows the difference between the number of health resort elements in the county with the most and the least health resorts, which is five. Third, we calculated relative range, the result of which has been $\mathrm{Q}=(6-1) / 1.6=5 / 1.6=3.1$. This result shows that the difference between the counties with the most and the least number of other health resort elements related to the average is 3.1. The fourth measure, the dual index shows the relation between the averages of the number of health resorts above the average distribution of the total number of health resorts and the average of the number of elements that had fallen below the average distribution of health resorts in the counties. The result of this quotient is $\mathrm{D}=3 / 0.5=6$. From this it can be concluded that there is a six-fold difference between the most developed and the least developed counties in terms of health resorts. There are nine counties in Hu ngary with better-thanaverage health resort supply, most of which are in Heves (six), Vas and Zala Counties (four in each). There are eleven counties with below-average health resort supply. The fewest health resorts are located in Borsod-Abaúj-Zemplén, Csongrád-Csanád, Győr-Moson-Sopron, Jász-Nagykun-Szolnok and Somogy Counties (one in each), the remaining six counties have no health resort at all. This difference in the quantity of health resorts is due to the difference between the natural geographical conditions and the requirements needed to be adequate for qualified health resort.

\section{Summary of polarisation measures}

Our results obtained by examining the spatial polarisation of natural treatment factors and medicinal water institutions are summarized in Table 7. Overall, it can be stated that the range ratio and the extent of dispersion, with the exception of other natural treatment factors, show high differences between counties in the case of medicinal waters and medicinal water institutions. However, based on the more reliable relative range and the results of the dual index it can be concluded that there is no significant spatial difference between the counties in terms of the examined factors, with the exception of the dual index of other natural treatment factors (N/A) and medicinal hotels (9.8).

\section{Examining Hungary's medicinal facilities}

We have grouped the natural treatment factors found in Hungary and the medicinal water institutions based on them as health facilities. Based on this, we have determined the developmnet of the counties by their health facilities with a dual index. The level of development in the counties of Hungary is illustrated in Figure 1. When examining the dual index of Hungary's aggregate health facilities, we obtained the result that the quotient of the average above the total average distribution and the average below the total average distribution of health facilities is $\mathrm{D}=33 / 12.2=2.7$. This means that there is a 2.7-fold difference between the most developed and the least developed counties in terms of health facilities. 


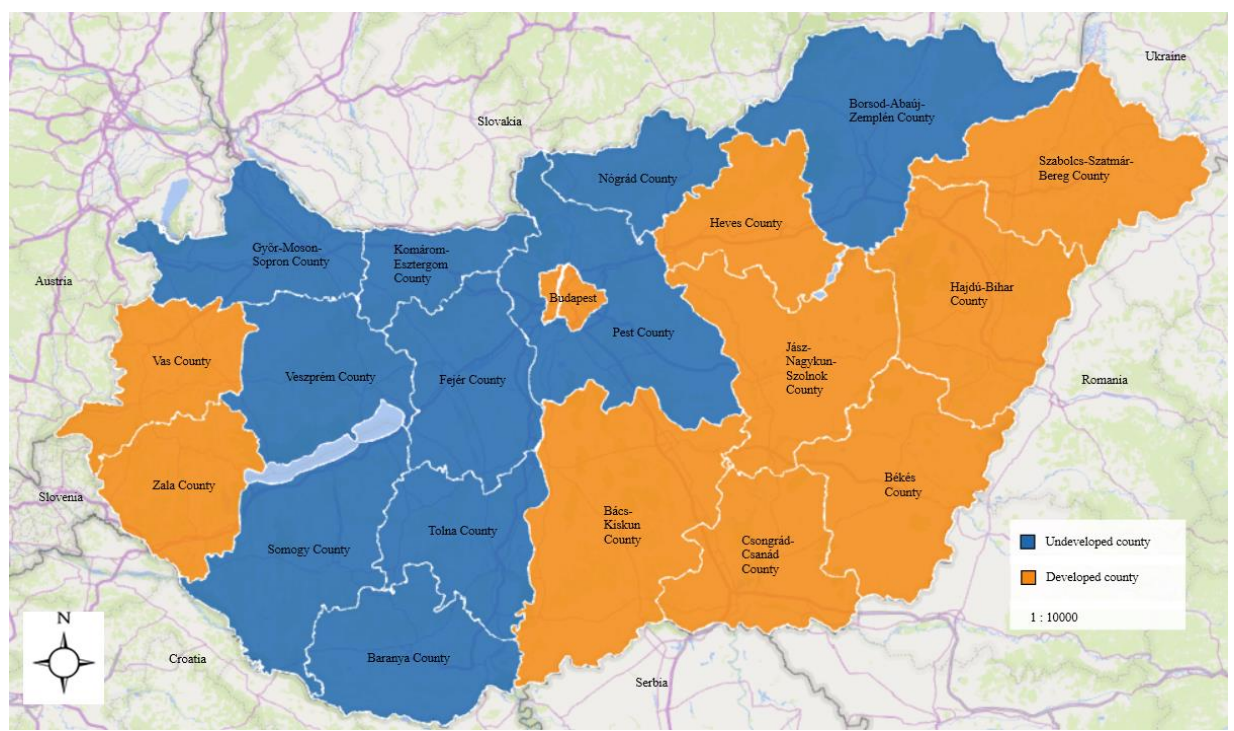

Figure 1. Development of counties (NUTS3) based on the number of health facilities (Source: Own editing with Microsoft Excel 2016 3D Map and own calculation)
There are nine counties (Békés, Csongrád - Csanád, Bács - Kiskun, Szabolcs - Szatmár - Bereg, Heves, Vas, Zala, Jász - Nagykun - Szolnok, Hajdú Bihar) in Hungary, besides Budapest, with better - than-average health facility supply, most of which are in Hajdú - Bihar County. There are ten counties with below-average health facility supply (Nógrád, Komárom Esztergom, Fejér, Veszprém, Tolna, Győ r- Moson - Sopron, Baranya, Borsod - Abaúj - Zemplén, Pest, Somogy). The fewest (two) can be found in Nógrád County. The number of medicinal waters and medicinal water institutions cause these differences in the quantity of natural treatment factors and medicinal water institutions in the counties.

\section{CONCLUSION}

Hungary has an international reputation for its natural treatment factors, especially for its medicinal waters due to the country's geographical constraits. These natural resources connect the fields of geography, balneology and tourism in an interdisciplinary way, the role of which is becoming more and more prominent today with the appreciation of health. Internationally and in Hungary, health tourism, including medical tourism trips aimed at preserving health, play an outstanding role in the preservation of health. Natural treatment factors and medicinal water institutions built on them open up remarkable opportunities for these trips. To achieve our research goal, we examined the spatial inequalities of natural treatment factors and medicinal water institutions with the use of secondary data.

Based on our results, we concluded that among the natural treatment factors of Hungary, medicinal waters are found in the largest amount, the number of which significantly differs in the counties, but based on the polarisation measures there is no significant spatial inequality between the counties. Further examining other natural treatment factors, we concluded that their number is low in the counties. From the results of the polarisation of medicinal water institutions based on natural treatment factors, it can be concluded that the basis of Hungarian medical tourism is provided by medicinal baths, the polarisation of which does not show significant differences between the counties. Furthermore, there are greater inequalities between medicinal hotels and health resorts with moderate polarisation in the counties. Overall, it can be stated that the fi ve counties east of the Tisza, as well as Heves, Bács-Kiskun, Vas and Zala Counties, and Budapest can be considered as developed counties in Hungary, the other ten counties can be described as underdeveloped in terms of health facilities.

These results suggest that spatial investigations play an important role in assessing the development of a country's tourism, so further research on the topic is recommended. Our results can form the basis of further researches in other countries of the Carpathian Basin, besides Hungary, which we propose to carry out for example in Romania, Slovakia, Slovenia, Ukraine, Serbia and Austria. The new results can be useful for the medical tourism decision makers.

\section{REFERENCES}

Ákoshegyi, Gy., \& Németh, I. (2006). Fürdők kézikönyve [Handbook of Baths], Magyar Fürdöszövetség, Hungary.

Babov, K., Gushcha, S., Koieva, K., Strus, O., Nasibulin, B., Dmitrieva, G., Arabadji, M., \& Plakida, A. (2020). Comparative assessment of biological activity of peloids of Ukraine of different genesis. Balneo Research Journal, 11(4), 467-471. http://dx.doi.org/10.12680/balneo.2020.380

Bachvarov, M., \& Liszewski, S. (2004). Spas in Central-Eastern Europe: Between Decline and Revitalisation. Greifswald: University of Greifswald Press, Germany, 41-50.

Bauer, I. (2008). The health impact of tourism on local and indigenous populations in resource-poor countries. Travel medicine and infectious disease, 6(5), 276-291. https://doi.org/10.1016/j.tmaid.2008.05.005

Bender, T., Bálint, G., Prohászka, Zs., Géher, P., \& Tefner, I.K. (2013). Evidenciákon alapuló hidro- és balneoterápiás vizsgálatok Magyarországon-Irodalmi összefoglalás és metaanalizis [Evidence-Based Hydro-and Balneotherapy Studies in Hungary - A Systematic Review and Meta-analysis]. LAM KID, 3(3), 41-48, (in Hungarian).

Bender, T., Bálint, G., Prohászka, Z., Géher, P., \& Tefner, I.K. (2014). Evidence-based hydro- and balneotherapy in Hungary - a systematic review and meta-analysis. Int. J. Biometeorol, (58), 311-323. https://doi.org/10.1007/s00484-013-0667-6

Bookman, M.Z., \& Bookman, K.R. (2007). Medical Tourism in Developing Countries. New York: Palgrave MacMillian, United States of America, 245.

Botterill, D., Pennings, G., \& Mainil, T. (2013). Medical tourism and transnational health care. Palgrave Macmillan, United States, U.K., Eurpoe.

Bujdosó, Z., \& Kovács, T. (2011). Észak-Magyarország [Northern Hungary]. In Magyarország idegenforgalmi régiói, 1-15, Pécsi Tudományegyetem, Hungary.

Bujdosó, Z. (2018). Comparison Of Tourism Administration In Two Central-European Countries. In XVI. Nemzetközi Tudományos Napok: „Fenntarthatósági kihivások és válaszok” - A Tudományos Napok Publikációi. Gyöngyös, 393-400, EKE Líceum Kiadó, Hungary.

Cantista, P. (2012). Balneology in Europe: results of a new survey. Anales de Hidrologia Medica, (6), 43.

Carrera, P.M., \& Bridges, J.F.P. (2006). Globalization and healthcare: understanding health and medical tourism. Expert Review Pharmacoeconomics Outcomes Research, 6(4), 447-454. 
Cook, P. (2008). What is health and medical tourism? In Reimagining Sociology. The Australian Sociological Association (TASA), 1-13, Victoria, Melbourne, Australia.

Cowell, F.A. (1977). Measuring Inequality. Phillip Allan. Oxford, United Kingdom.

Csapó, J., \& Marton, G. (2017). The role and importance of spa and wellness tourism in Hungary's tourism industry. Czech Journal of Tourism, 6(1), 55-68.

Csermely, M. (2009). Fizioterápia. Medicina, Budapest, Hungary.

Dávid, L., Jancsik, A., Rátz, T., \& Dávid, L. (2007). Turisztikai erőforrások: A természeti és kulturális eröforrások turisztikai hasznosítása [Tourism resources]. Perfekt Kiadó, Budapest, Hungary, (szerk).

Dávid, L., Remenyik, B., \& Szücs, Cs. (2013). Special health tourism products in the Bükk and Mátra regions. In Health, tourism and hospitality: spas, wellness and medical travel. 335-339, New York, Routledge, United States of America.

Fritz, P. (2019). Terápiás rekreáció. In Alapfogalmak és jelentéseik a rekreáció területén. Rekreáció mindenkinek [Basic concepts and their meanings in the field of recreation. Recreation for everyone]. III. Miskolc Egyetemi Kiadó, Hungary, 124-131.

Géher, P., Bender, T., \& Ákoshegyi, Gy. (2016). Magyarország gyógyfürdöi és gyógyvizes termálfürdöi [Spas and thermal baths in Hungary]. Magyar Balneológiai Egyesület, Budapest, Hungary.

Goll, M. (2010). Ageing in the European Union: where exactly? Rural areas are losing the young generation quicker than urban areas. Population and social conditions Statistics in focus. Agriculture and fisheries, (26), 1-16.

Gutenbrunner, C., Bender, T., Cantista, P., \& Karagülle, Z. (2010). A proposal for a worldwide definition of health resort medicine, balneology, medical hydrology and climatology. Int J Biometeorol, (54), 495-507. https://doi.org/10.1007/s00484-010-0321-5

Hall, C.M. (2013). Medical Tourism: The ethics, regulation, and marketing of health mobility. New York, United States of America.

Hojcska, Á.E., \& Kurth, G. (2016). A mozgásszervi betegségek kezelésében társadalombiztosítási támogatással igénybe vehető gyógyfürdőellátások és jogi környezetük [In the treatment of musculoskeletal diseases, can be used medicinal water treatments with social security support and their legal environment]. In Fürdővárosok környezete, 153-177, Magyar Fürdővárosok Szövetsége, Túrkeve, Hungary.

Ilieş, D.C., Blaga, L., Josan, I., Baias, St., Morar, C., \& Herman, G. (2010). Cross Border Natural Parks, Support For Regional Development. Case Study Of The Northern And Western Romanian Border. Revista Română de Geografie Politică, Year, XII(1), 126-139. http://rrgp.uoradea.ro/art/2010-1/11_OK_IliesDC+.pdf

Ilies, D.C., Buhas, R., Ilies, M., Ilies, A., Gaceu, O., Pop, A.C., Marcu, F., Buhas, S.D., Gozner, M., \& Baias, S. (2018). Sport Activities And Leisure In Nature 2000 Protected Area - Red Valley, Romania. Journal of Environmental Protection and Ecology, 19(1), 367-372.

Incze, R., Papp, B., Burghele, B.D., Cosma, C., \& Gyila, S. (2016). Follow-up measurements to estimate the exposure to patients in the mofettes from Covasna county (Romania). Romanian Journal of Physics, 61(7-8), 1320-1329.

Jordan, P. (1999). Atlas of Eastern and Southeastern Europe - International Tourism Attractions 1998. Österreichisches Ost-und Südeuropa Institut, (ed.) Vienna, Austria, 2-12.

Kovács, A. (2017). A fizioterápia története. In Bizonyítékokon alapuló fizioterápia. Medicina, Budapest, Hungary.

Lăzărescu, H., Simionca, I., Hoteteu, M., \& Mirescu, L. (2014). Speleotherapy - modern bio-medical perspectives. J Med Life, 7(2), 76-79. PMID: 25870679; PMCID: PMC4391363.

Modelska, M., Buczyński, S., Błachowicz, M., Heidemann, M., Grzęda, O., \& Łukasz Karkoszka, L. (2015). The Mofetta Tylicz - an example of carbonated water springs in thearea of Tylicz (Beskid Sądecki, the Carpathians). Geoscience Records, (1-2), 27-33. https://doi.org/10.1515/georec-2015-0004

Major, K., \& Nemes Nagy, J. (1999). Területi jövedelem-egyenlőtlenségek a kilencvenes években [Spatial income inequalities in the 1990s]. Statisztikai Szemle, (6) 397-421, (in Hungarian).

Molnár, Cs., \& Dávid, L. (2010). Egészségturizmus [Health tourism]. Károly Róbert Főiskola, Magyarország, Gyöngyös, Hungary.

Molnár, T. (2015). Empirikus területi kutatások [Empirical spatial researches]. Akadémiai Kiadó, Budapest, Hungary.

Munteanu, C., Munteanu, D.N., \& Dogaru, G. (2020). Balneology in 2020. Balneo Research Journal, 11(3), L1. http://dx.doi.org/ 10.12680/balneo.2020.346.L1

Nagy, K., Kávási, N., Kovács, T., \& Somlai, J. (2008). Radon Therapy And Speleotherapy In Hungary. Press Therm Climat, (145), $219-225$.

Nemes Nagy, J. (2006). A területi versenyképesség elemzési módszerei [Methods of analysis of spatial competitiveness] In Régiók és települések versenyképessége, 69-83, MTA Regionális Kutatások Központja, Pécs, Hungary.

Németh, N. (2005). A területi polarizáltság méröszámai [Measures of spatial polarization]. ELTE Regionális Földrajzi tanszék, Hungary.

Noether, G. (1955). Use of the Range Instead of the Standard Deviation. Journal of the American Statistical Association, 50(272), 10401055. https://doi.org/10.2307/2281203

Price, J.H., \& Murnan, J. (2004). Research Limitations and the Necessity of Reporting Them. American Journal of Health Education, (35), 66-67.

Szabó, Z. (2011). Inanspruchnahme von Heilbad-Dienstleistungen im Lichte von Verbrauchererhebungen. Nemzetközi Tudományos Konferencia Tanulmánykötet,121-134, Nyugat-magyarországi Egyetem Kiadó, Győr, Hungary.

Szabó, Z. (2012). A special opportunity of the use of natural resources: sustainable bath-development through the eyes of mayors. In Kincseink védelmében: Fenntarthatóság és Környezettudatosság a turizmusban, 10-22, Sopron, Nyugat-magyarországi Egyetem Kiadó, Hungary.

Szabó, Z. (2017). The development offer values of tourism in Hungary: Az egészségturizmus kínálati értékeinek fejlesztése Magyarországon. In The values of spa towns, agyar Fürdővárosok Szövetsége, Szentes, Hungary, 36-47.

Teoibas-Serban, D., Iordache, L., \& Blendea, D. (2020). The ascent and decline of a great balneological resort: Pucioasa. Balneo Research Journal, 11(4), 498-500. http://dx.doi.org/10.12680/balneo.2020.387

Tippett, L. (1925). On the Extreme Individuals and the Range of Samples Taken from a Normal Population. Biometrika, 17(3/4), 364-387. https://doi.org/10.2307/2332087

Van Tubergen, A., \& Van der Linden S. (2002). A brief history of spa therapy. Annals of the Rheumatic Diseases, 61(3) $273-275$.

Williamson, J.G. (1965). Regional inequality and the process of national development: a description of the patterns. "Economic Development and Cultural Change" 4.

Zsarnoczky, M. (2017). New Innovations for Senior Care. Vadyba Journal of Management, 45-50.

Zsarnóczky, M. (2019). Az egészségturizmus folyamatainak terminológiai változásai [Terminological changes in health tourism processes]. Turizmus Bulletin, XIX(1), 36-44, (in Hungarian).

*** ÁNTSZ (2019). https://www.antsz.hu/felso_menu/temaink/termeszetes_gyogytenyezok, Download: 2020. 12.21.

Article history: Received: 21.02.2021 Revised: 11.04.2021 Accepted: 01.06.2021 Available online: 30.06 .2021 